\title{
Quality of education as a requirement of modern society
}

\author{
Vera Demina $^{1}$, Svetlana Demina ${ }^{2,}$, Oksana Kozhukalova ${ }^{3}$ and Irina Zayakina ${ }^{4}$ \\ ${ }^{1}$ Moscow Pedagogical State University, Moscow, Russia
}

\begin{abstract}
The aim of the work is to study the compliance of the quality of education in Russia with the requirements determined by the needs of the Russian society. The article reveals the genesis of such categories as" quality of education "and"quality of products and services". The features of educational services as a public good in the forms of market relations are revealed. The structure and role of various consumers of educational services are defined separately, and a classification of the needs and requirements of consumers to the quality of education is proposed. In the course of the research, such methods as analysis and synthesis, induction and deduction, and statistical methods for studying the economic situation were used. The empirical base of the research is scientific works of Russian and foreign authors on the problems of education quality, National standards of the Russian Federation and International standards in the field of quality, the Federal law "on education in the Russian Federation", Federal state educational standards of the Russian Federation, official data of the Federal Treasury and the Federal state statistics service of the Russian Federation.
\end{abstract}

\section{Introduction}

In the modern world, education is de facto recognized as an important factor in the formation of a person's personal potential, which, in turn, determines their social status, competitiveness in the labor market and, in many ways, the quality of life. Moreover, development based on human capital and qualitative improvement of the latter contribute to long-term balanced economic growth. Based on this, we can conclude that the quality of education is, first, one of the driving forces for the development and growth of not only the individual's personal potential, but also the labor potential of organizations, industries, regions, the country and society as a whole. Secondly, the quality of education is a factor in the formation of competitive advantages of a specialist in the labor market, as well as the organization, region and country as economic systems and recipients of investment.

The aim of the work is to study the compliance of the quality of education in Russia with the requirements determined by the needs of the Russian society. To achieve this goal, the following tasks were set and solved:

- the category "quality of education" is revealed;

- the adequacy of the quality of Russian education to the needs of Russian society is determined;

\footnotetext{
*Corresponding author: sa.demina@mpgu.su
} 
- the author presents his own vision of bringing the quality of Russian education in line with the needs of the Russian society.

\section{Materials and methods}

In the course of the research, such methods as analysis and synthesis, induction and deduction, and statistical methods for studying the economic situation were used.

The empirical base of the research are scientific works of Russian and foreign authors on the problems of education quality, National standards of the Russian Federation and International standards in the field of quality, the Federal law "on education in the Russian Federation", Federal state educational standards of the Russian Federation, official data of the Federal Treasury and the Federal state statistics service of the Russian Federation.

\section{Results}

To trace the genesis of the "quality of education" category, we will focus on such categories as" education"," quality","quality of products and services".

Article 2 of the Federal Law "on education in the Russian Federation" defines education as follows: "a single purposeful process of education and training that is a socially significant good and is carried out in the interests of a person, family, society and the state, as well as a set of acquired knowledge, skills, values, experience and competencies of a certain volume and complexity for the purpose of intellectual, spiritual, moral, creative, physical and (or) professional development of a person, meet their educational needs and interests" [1].

The definition above is followed by important features of education: first, education is a process that is socially significant boon and the results of that process; secondly, the education is carried out in the interests of the individual (consumer) and stakeholders; third, education is aimed at comprehensive human development and meeting their educational needs and interests.

The definitions of "quality" and "quality of products and services" are given in table 1.

Table 1. Concept of quality.

\begin{tabular}{|c|c|c|}
\hline Term & Definition of concept & Source \\
\hline Quality & $\begin{array}{l}\text { The degree to which the aggregate and inherent } \\
\text { characteristics meet the requirements. } \\
\text { Notes: } \\
\text { The term "quality" can be used with adjectives } \\
\text { such as bad, good, and excellent. } \\
\text { The term "inherent "is the opposite of the term" } \\
\text { assigned "and means"present in something". } \\
\text { A distinctive property of something is a } \\
\text { characteristic. The characteristic can be } \\
\text { qualitative or quantitative. } \\
\text { Requirement - need or expectation that is stated, } \\
\text { generally implied or obligatory. Requirements } \\
\text { can be put forward by various stakeholders. }\end{array}$ & $\begin{array}{l}\text { Interstate standard GOST ISO } \\
9000-2011 \text { "of the quality } \\
\text { management System. Basic } \\
\text { provisions and dictionary". }\end{array}$ \\
\hline $\begin{array}{l}\text { Quality of the } \\
\text { organization's } \\
\text { products and } \\
\text { services }\end{array}$ & $\begin{array}{l}\text { It is determined by the ability to satisfy } \\
\text { consumers and by intentionally or } \\
\text { unintentionally influencing relevant } \\
\text { stakeholders. } \\
\text { The quality of products and services includes not } \\
\text { only the performance of functions in accordance } \\
\text { with their purpose and their characteristics, but }\end{array}$ & $\begin{array}{l}\text { National standard of the } \\
\text { Russian Federation GOST R } \\
\text { ISO 9000-2015 " quality } \\
\text { management Systems. Basic } \\
\text { provisions and dictionary" } \\
\text { (revised edition). }\end{array}$ \\
\hline
\end{tabular}


also the perceived value and benefit to the consumer.

Source: compiled by the authors.

Thus, from the definitions of terms given in table 1, it follows that quality, including products and services, is defined as compliance with requirements in the form of needs or expectations.

Analysis of the literature in the field of quality of education shows that today there are many scientific approaches that reflect the depth of study of various indicators of quality of education. Differences in approaches to the interpretation of the quality of education are presented in table 2.

Table 2. Differences in approaches to the interpretation of the quality of education.

\begin{tabular}{|c|c|}
\hline $\begin{array}{c}\text { Group of } \\
\text { researchers }\end{array}$ & nce of the apI \\
\hline $\begin{array}{l}\text { Sankin L. A, } \\
\text { Tonkonogaya E. } \\
\text { P. }\end{array}$ & $\begin{array}{l}\text { The approach is based on a comparison of socially significant personal qualities } \\
\text { and the level of knowledge, skills and abilities that were obtained in the learning } \\
\text { process. In this regard, the main parameters of the quality of education are goals, } \\
\text { technologies, conditions and personal development. }\end{array}$ \\
\hline $\begin{array}{l}\text { Selezneva N. A., } \\
\text { Subetto A. I. }\end{array}$ & $\begin{array}{l}\text { Compliance of education with the requirements of development of social and } \\
\text { cultural institutions and systems is key in the assessment (Subetto A., "quality } \\
\text { management System in higher education", 2002). }\end{array}$ \\
\hline $\begin{array}{lr}\text { Zhigadlo } & \text { A., } \\
\text { Puzikov } & \text { A., } \\
\text { Shutkina Zh. A. }\end{array}$ & $\begin{array}{l}\text { The quality of education is considered, on the one hand, as a set of educational } \\
\text { characteristics of a graduate, and on the other - as the degree of achievement of } \\
\text { specific educational goals predicted for the zone of potential development of the } \\
\text { student's personality (Zhigadlo A., Puzikov V., "Quality of training and } \\
\text { employment of young specialists: a sociological aspect", 2007). }\end{array}$ \\
\hline $\begin{array}{l}\text { Potashnik M. M., } \\
\text { Reana A. A. }\end{array}$ & $\begin{array}{l}\text { The quality of education is determined primarily by the measure of achievement } \\
\text { of educational goals. This measure is expressed as the ratio of goal and result at } \\
\text { the level of a specific education system and at the level of a specific ES. } \\
\text { The approach highlights various parameters in the assessment of the result of a } \\
\text { particular person's education by correspondence [2]. At the Same time, M. M. } \\
\text { Potashnik's goals are set only operationally and are predicted in the zone of } \\
\text { predicted student development (M. Potashnik, "Quality of education: problems } \\
\text { and management technologies", 2002). }\end{array}$ \\
\hline $\begin{array}{l}\text { Rubin Yu. B., } \\
\text { Suchkova L. A. }\end{array}$ & $\begin{array}{l}\text { The approach is focused on identifying different consumers of education and } \\
\text { different subjects of the educational process. } \\
\text { Thus, Suchkova L. A. suggests considering the quality of education from the } \\
\text { point of view of the following subjects and consumers of its results: society, a } \\
\text { specific educational institution and a student (Suchkova L., "Fundamentals of } \\
\text { system assessment of the quality of education", 2005). }\end{array}$ \\
\hline $\begin{array}{l}\text { Baranovsky A. } \\
\text { I., Eliseeva T. I. }\end{array}$ & $\begin{array}{l}\text { The key parameter of the assessment is the degree to which education meets the } \\
\text { needs and expectations of the individual and society. The content of education, } \\
\text { its forms and methods, as well as material-technical base and structure of the } \\
\text { faculty is determined by the aggregate performance indicators and indicators of } \\
\text { the process of education in a particular OU (Baranowski A., "ways of increase } \\
\text { of competitiveness of educational services", 2003). }\end{array}$ \\
\hline \begin{tabular}{lr|} 
Maltseva G. & I., \\
Bordovsky & G. \\
A., Nesterov & A. \\
A., Trapitsyn & S. \\
Yu.
\end{tabular} & $\begin{array}{l}\text { The emphasis is placed on the ability of a particular ES to meet established and } \\
\text { projected needs. The quality of education is considered here as a property that } \\
\text { determines the ability of educational institutions to meet the needs of consumers } \\
\text { at different levels (Bordovsky G, Nesterov A., Trapitsyn S., "quality } \\
\text { Management of the educational process", 2001). }\end{array}$ \\
\hline
\end{tabular}




\begin{tabular}{|l|l|}
\hline & \\
\hline $\begin{array}{l}\text { Zvonnikov V. I., } \\
\text { Selezneva N. A. }\end{array}$ & $\begin{array}{l}\text { The quality of education is considered from the point of view of ES ability to } \\
\text { satisfy stated and implied needs as well as from the point of view of achievement } \\
\text { of planned results taking into account the internal capacity and external } \\
\text { conditions of the object of study. As a result, the approach combines both the } \\
\text { results of the learning process and the compliance of these results with diverse } \\
\text { needs, goals, standards and requirements [3, p. 11]. }\end{array}$ \\
\hline $\begin{array}{l}\text { Ilyenkova S. D., } \\
\text { Ilyenkova N. D., } \\
\text { Mkhitaryan V. S. }\end{array}$ & $\begin{array}{l}\text { Since it is the teacher who transmits this knowledge using various teaching } \\
\text { methods, the quality of education itself is determined primarily by the quality } \\
\text { of the teaching staff, that is, the quality of the carrier of knowledge, skills and } \\
\text { abilities (llyenkova S. "quality Management: textbook for universities", 2006). }\end{array}$ \\
\hline
\end{tabular}

Source: compiled by the authors.

As can be seen from the review of differences in approaches to the interpretation of the quality of education, each definition of quality has one General provision: the quality of education and its components are compared with certain basic attitudes, norms, and standards. These basic parameters serve as a kind of standard for evaluating the quality of education.

Thus, the requirements of state educational standards today almost completely determine the entire range of conditions and processes in Russian educational institutions. Of course, each educational institution, based on the Federal state educational standard, can independently introduce criteria, assessment tools and create assessment methods for disciplines and state final certification, thus forming an internal quality assessment system. However, in order to pass the licensing and accreditation procedure, it is necessary, first of all, to comply with the requirements of state standards. Therefore, we can say that in Russia, the quality of state requirements largely determines the quality of education itself.

Article 2 of the Federal Law "on education in the Russian Federation" defines the quality of education as follows:" comprehensive characteristics of educational activities and training of students, expressing the degree of their compliance with Federal state educational standards, educational standards, Federal state requirements and (or) the needs of an individual or legal entity in whose interests educational activities are carried out, including the degree of achievement of the planned results of the educational program " [1].

Thus, the Law highlights the requirements of standards and the needs of students in assessing the quality of education.

The quality of education of accredited educational institutions, including universities that have passed the accreditation procedure, is evaluated in accordance with the requirements of Federal state educational standards. Federal state educational standards - FSES) are a set of requirements that are mandatory for the implementation of basic educational programs (BEP) of primary General, basic General, secondary (full) General, primary professional, secondary professional and higher professional education by educational institutions that have state accreditation. Thanks to the FSES, the unity of the educational space is ensured, as well as the continuity of the BEP from primary to higher education.

Each FSES includes three types of requirements:

1. requirements for the structure of the BEP, including the ratio of mandatory parts and parts determined by participants in the educational process, as well as their volume;

2. requirements to conditions of implementation of the BEP (personnel, financial, logistical and other conditions);

3. requirements for the results of the BEP.

It should be noted that the application of standards in education is also typical for other countries. In particular, The study by M. Townsley analyzes the areas of intersection of the concepts of "competence-based learning" and "standards-based education". The latter is most common in the American academic community and consists in establishing clear indicators 
of learning outcomes in basic academic disciplines that apply to all students, standardizing the principles of selecting educational content, and standardizing requirements for teachers [4].

In 2009, the Common Core State Standards program was tested in 45 States and the district of Columbia as a result of the phased implementation of standards-based education strategies. Based on basic state standards, most States have adopted standards adapted to local conditions. The second generation of Russian FSES is based on a similar understanding of learning outcomes [5].

Of course, it is impossible to identify the concepts of educational services and education. Because in order to assess the level of education and educational services, different criteria are needed. High-quality service delivery may be accompanied by low educational indicators due to low motivation and activity of students.

According to Kazakova I. A., to determine the quality of educational services, the following four components are necessary: the quality of the object, the quality of the subject, the quality of the process of providing educational services, as well as the degree of customer satisfaction [6].

The author notes that these components are in a synergistic interaction and the reduction of one of them leads to a decrease in the quality of the others, and, as a result, there is an increase in dissatisfaction with consumers of educational services.

According to the classification of V. A. Kachalov, there are seven factors of education quality that can be grouped into three groups [7].

The first group includes indicators that characterize the quality of the subject receiving educational services (entrant, student, graduate student, listener). To determine them, the results of entrance tests and/or use scores are used.

The second group of indicators that characterize the quality of the object of providing educational services includes the following factors:

- quality of management, consisting of goals, principles, methods, structure, organization of planning;

- quality of the project for providing ES, which implies the content of training programs, structure;

the quality of the resource provision process the provision of the shelter (personnel, material-technical, methodological and other conditions).

The third group, which characterizes the quality of the process of providing ES, includes:

- quality of implementation and organization of the used technologies for providing ES;

- quality of control over the process of providing ES;

- quality of control over the results of providing ES.

Common among all approaches is that it is the University that forms the system of providing OU, thanks to close interaction with customers and recipients of ES, who are able to objectively assess the quality of the education system [8].

Therefore, the development and application of the internal audit system for the quality of educational services as a broader system than just control becomes relevant for the University, since the audit includes Analytics, forecasting trends, and adjusting the development of educational programs. At the same time, the system of state control and audit of the quality of education is supplemented by an intra-University system for ensuring the quality of education.

The state carries out quality control in the field of education by conducting inspections and taking appropriate measures based on them. At the same time, the compliance of the content and quality of training of students in the educational programs of the Federal state educational system, which have state accreditation, is checked.

In particular, the Ministry of education and science of the Russian Federation sets the values of basic regulatory costs for the provision of public services for the implementation 
of educational programs of higher education. It is required to provide information about the pedagogical (scientific and pedagogical) staff, including the level of education, work experience, academic degree, title, terms of employment (at the main place of work; on the terms of internal / external part-time work; on the terms of a civil contract), etc. We check the availability of library, material and technical resources, the state of the information and educational environment of the University, etc. These indicators demonstrate the possibility of providing quality education [9].

The use of the quality audit system for educational services makes it possible to assess the quality of educational services not only by controlling and authorized bodies, but also by students themselves, as well as by graduates and employers who are the final consumers of educational services.

The creation of an audit system for the quality of educational services that takes into account the interests of all subjects of the educational process is particularly relevant in the context of reducing Federal budget expenditures on the development of a network of national research universities.

According to the Ministry of science and education of the Russian Federation, the share of the Federal budget in financing the development programs of national research universities (NRU) for the period 2009-2019 was constantly decreasing. At the same time, the share of funding from the budgets of the constituent entities of the Russian Federation grew [10].

So, if in 2009 the share of funding for national research universities from the budgets of the Russian Federation's constituent entities was only $2 \%$, by 2017 this figure was $15 \%$. The drop in funding occurred in 2018-2019: the share of NRU funding from the budgets of the Russian Federation's constituent entities was $14 \%$ and $6 \%$, respectively [Ibid.].

Given the different financial opportunities of the regions, as well as the General economic situation in the country, there is an acute shortage of funds for financing universities at the regional level. In the current conditions, the task of creating an effective system of leading universities seems impossible for most regions.

Analysis of expenditures of the consolidated budget of the Russian Federation and budgets of state extra-budgetary funds shows that the volume of education funding is growing in absolute terms, but the dynamics of education funding in Russia is much lower than in such areas as" environmental Protection"," Housing and communal services"," Culture, cinematography", as well as"Physical culture and sports". Spending on social policy, the media, and health only increased at a slower rate, as shown in figure 1. 


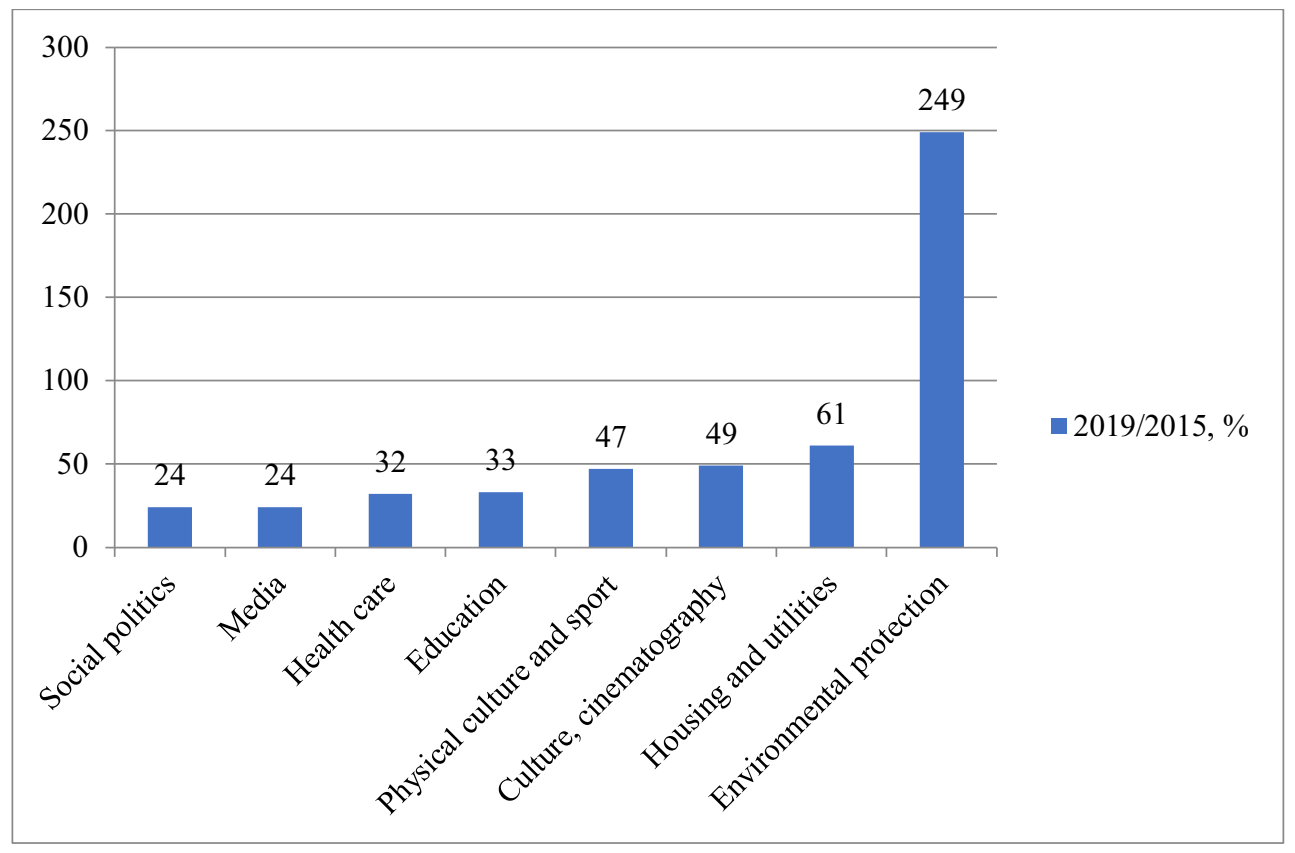

Fig. 1. Dynamics of expenditures of the consolidated budget of the Russian Federation and budgets of state extra-budgetary funds for 2015-2019, \%. Source: Compiled by the authors on the basis of data from the Federal Treasury on the execution of the consolidated budget of the Russian Federation and the budgets of state extra-budgetary funds (https://roskazna.gov.ru).

A detailed analysis of the structure of spending on education by level of education allows us to conclude that during the study period, expenditures on applied scientific research in the field of education increased the least (the growth in 2015-2019 was 10\%).

Spendings on higher education increased by only $13 \%$, while spendings on vocational training, retraining and advanced training increased by $122 \%$ over the same period.

The growth in spending on pre-school education was $39 \%$, on General education- $17 \%$, secondary vocational education-35\%, youth policy-39\%, spending on other issues in the field of education increased by $41 \%$, the dynamics of changes is shown in figure 2 . 


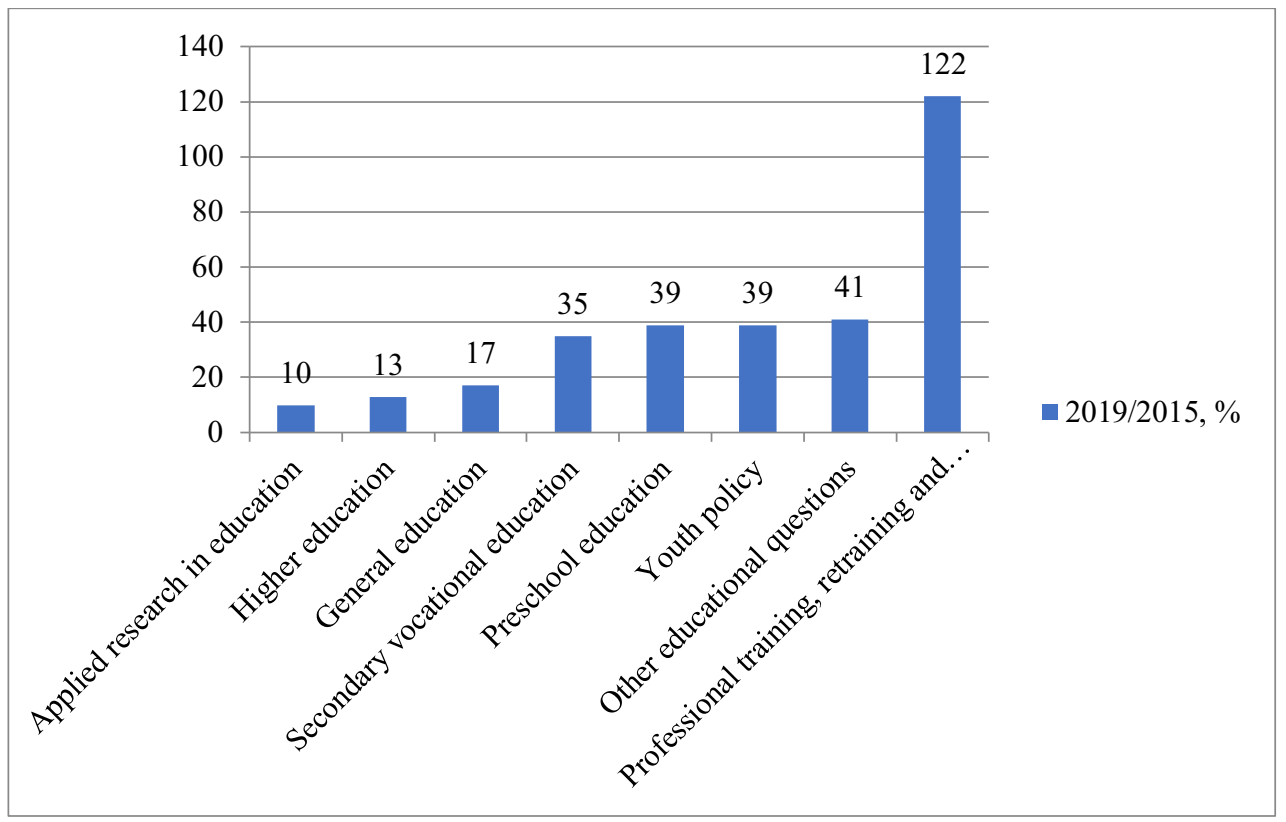

Fig. 2. Dynamics of expenditures of the consolidated budget of the Russian Federation and budgets of state extra-budgetary funds for education 2015-2019, \%. Source: Compiled by the authors on the basis of data from the Federal Treasury on the execution of the consolidated budget of the Russian Federation and the budgets of state extra-budgetary funds (https://roskazna.gov.ru).

\section{Discussion}

On the territory of the Russian Federation within the framework of the action Plan ("road map») "Changes in social sectors aimed at improving the efficiency of education and science" the task is to create a system of leading universities in the country. The program is aimed at supporting Universities that have confirmed the implementation of priority areas of development of the country on the basis of developed projects. The number of educational organizations that have received additional financial support from the state under Project 100 is limited by the number of grants offered by the state. The remaining universities, of which there are more than 1,400 in Russia, realize their interests, activity and process potential and ensure the achievement of quality indicators of education, both by rationalizing the disposal of available funds, and by funding from participants in the educational process or, less often, from potential employers interested in attracting graduates to their employees.

Increasing the role of education in modern society is an indisputable fact not only in the scientific world, but also in the everyday consciousness of every average citizen of the planet from school age. Awareness of the importance of intellectual development, which is impossible without a wide range of acquired knowledge, increases during the period of choosing a higher or secondary professional educational institution, and then its rating is taken into account, determined by the quality indicators of the educational organization. The choice of an educational organization is determined by the requirements for the quality of educational services on the part of its consumers who have conscious needs.

In this regard, it is very important to distinguish the concepts of educational services as a public good from educational services as a market good. let's analyze the point of view on these categories. The "public good", in contrast to the market good, is available to all citizens, regardless of welfare, is not a subject of dispute and is financed from the state budget. 
The requirements of the" knowledge society " determine the requirements for educational services, indicating its decisive role in the development of society. The growing demand of public institutions for quality education is both the basis for the successful development of modern economy and its important result. Quality education should not only be available, but also mandatory. Representatives of the state authorities, providing the possibility of different forms of educational services, will be able to achieve the set strategic goals of the society's development.

The level of education of the population, the number of students enrolled in various educational programs, and the number of years of study are the most important indicators of the country's economic development. With the help of an educational service as a market bug, access to knowledge is expanded at the expense of economic institutions interested in obtaining it. Educational services as a benefit are provided not only by the state, but private educational institutions can also provide this service free of charge, for example, for talented children. Thus, the features of educational services as a public good are present in the activities of market forms of relations. We will discuss the ambiguity of this form below.

Sources of funding for educational organizations are determined by the demand for their services or by consumers, as well as by their affiliation status, i.e., their relationship to state or commercial (non-state) organizations. Students, students, families, businesses and organizations, the state and society as a whole are identified as consumers of educational services.

Enterprises as economic entities use the intellectual potential of employees (graduates of educational organizations), which means that they are consumers of educational services. Economists have analyzed in detail the productive nature of education as a factor of competitiveness and profitability of organizations, which determines the need for highquality educational services and explains not only the role of enterprises as consumers of educational services, but also as its sponsors [11]. Competitive and profit - oriented enterprises place high demands on the education of their employees, conducting three-stage competitive selections for vacant jobs (knowledge of the General education program, knowledge of foreign languages and knowledge of the profession) and certification for the following competencies: functional knowledge, communication skills, teamwork, conflict management, idea generation, etc. $[12,13]$.

The state, local and central authorities are political institutions that ensure the effective functioning and interaction of public institutions by improving the overall level of education. these institutions are directly interested in improving the quality of education that ensures economic growth, the well-being of the entire society and the achievement of high international ratings [14]. The source of public expenditures and future income from the interaction and impact on the world of highly intelligent individuals are tax payments as a result of the work of citizens who have the right to influence the disposal of their income, and, consequently, to influence, for example, the distribution of benchmarks for admission of applicants studying at the expense of the state budget [15].

Separately, it is necessary to define the role of parents in this issue. It is parents who pay for educational services for their children in order to get their children a prestigious highpaying job in the future. Students also often become subjects that act as sources of funding for educational services, finding jobs in offices as assistant managers or in McDonald's as waiters to pay for their education. But if in Russia educational services are paid for from the state or family budget, then in Western European universities in 2013 income from tuition fees for families was $16 \%$, and from endowment (charitable assistance) - up to $30 \%$, which, according to researchers, affects the high efficiency of universities and sponsors [16].

The variety of sources of funding contradicts the view that public goods are produced only by the state, which does not accurately reflect the development and needs of modern 
society, which has been characterized as a "knowledge society". The needs of consumers of educational services determine the requirements for it, which is reflected in table 3.

Table 3. Needs and requirements for the quality of education by consumers.

\begin{tabular}{|c|c|c|}
\hline $\begin{array}{l}\text { Consumers } \\
\text { (sources of funding) } \\
\text { of educational } \\
\text { services }\end{array}$ & Needs & Requirements for educational services \\
\hline State & \begin{tabular}{|l|}
-high living standard; \\
- economic growth; \\
- reducing crime; \\
- compliance of society's life \\
with scientific and \\
technological progress; \\
- high ratings in international \\
statistics.
\end{tabular} & $\begin{array}{l}\text {-level of knowledge of graduates; } \\
\text { - level of scientific research; } \\
\text { - quality staff of teachers; } \\
\text { - the volume of educational and methodical } \\
\text { work; } \\
\text { - scientific and technical base; } \\
\text { - provision of libraries with literature; } \\
\text { - citation index of scientific publications; } \\
\text { - international academic mobility; } \\
\text { - participation of students in scientific } \\
\text { events; } \\
\text { - formation of competencies; } \\
\text { - employment of graduates; } \\
\text { - structure of motivation to study } \\
\text { openness and accessibility of information } \\
\text { about organizations that carry out } \\
\text { educational activities, etc }\end{array}$ \\
\hline $\begin{array}{l}\text { Businesses/ } \\
\text { firms }\end{array}$ & $\begin{array}{l}\text {-high competitive positions; } \\
\text { high profit; - entering new } \\
\text { markets; - attracting investment } \\
\text { - qualified personnel, etc. }\end{array}$ & $\begin{array}{l}\text { Formation: } \\
\text { functional and General cultural } \\
\text { competencies; - responsibilities; - ability to } \\
\text { work in a team; - ability to generate ideas } \\
\text { and be responsible for them; - ability to self } \\
\text { development, etc. - ability to develop and } \\
\text { make effective decisions; -information and } \\
\text { computer literacy skills; - readiness for } \\
\text { emergency actions; - ability to organize } \\
\text { activities and control quality; - sense of } \\
\text { duty; - leadership qualities; - ability to work } \\
\text { in a team and collaborate; - integrity and } \\
\text { decency; - communication and public } \\
\text { speaking skills; - ability to project activities }\end{array}$ \\
\hline Families & $\begin{array}{l}\text { - high level and quality of life; } \\
\text { - moral satisfaction; - } \\
\text { intellectual development; - } \\
\text { social status, etc. }\end{array}$ & $\begin{array}{l}\text { Formation: } \\
\text { functional and general cultural } \\
\text { competencies; - employment opportunity. }\end{array}$ \\
\hline Sponsors & $\begin{array}{l}\text { - a stable society without social } \\
\text { disasters }\end{array}$ & $\begin{array}{l}\text { Formation: } \\
\text { - general cultural competencies; } \\
\text { - functional competencies. }\end{array}$ \\
\hline
\end{tabular}

Source: compiled by the authors.

The formation of professional competencies is the main requirement for educational services in modern society. Conditions and the process of formation of which in Russia is evaluated by state bodies. Assessment of the quality of educational services includes a subjective component, which is determined both by the nature of changes in labor market requirements and by the assessment of the usefulness of knowledge by consumers 
themselves. Scientists use various methods to analyze the quality of educational services provided [17].

To assess customer satisfaction, economic analysis uses a set of methodological tools. To assess the quality of service in the world practice, the SERVQUAL, ACSI, ECSI, and CSI methods are often used,we should also note the student satisfaction Index $[18,19]$. The emphasis in the methods is mainly on the seller's feedback with the client, where the denominator in the assessment of satisfaction is the level of expectations [20].

There is currently no national satisfaction index in Russia. Customer satisfaction of educational services is an important strategic goal of the management of any educational organization. The purpose of satisfaction assessment is to identify the strengths and weaknesses of an educational organization that seeks to attract the most talented young people to the Institute, using high student satisfaction, which is an indicator of quality and in turn works to improve it in the future. But most importantly, satisfaction with the requirements of consumers with an educational service contributes to the attractiveness of its receipt, the development of those educational organizations that meet the requirements of the time and the development of the entire society and meet the socio-economic needs of society.

Ensuring that the quality of education in Russia meets the requirements stipulated by the needs of Russian society should be provided with financial support from interested parties, primarily the state, at the level of at least 5\% of GDP. Lower contributions for the development of education in the country will not allow access to the expanded reproduction, to bring the quality of Russian education to modern conditions of domination of the Megatrends of the fourth industrial revolution and the conditions of formation of the digital economy, introducing innovative technologies and intellectualization of labor in all industries and at all levels of the production process.

At the same time, the model of education financing in Russia should be multi-level and multi-sided. The new model should: ensure an adequate level of funding at the Federal level; encourage local authorities, the business community and sponsors to support the OU at the regional level; influence students and their parents on the quality of educational services, including by taking their opinions into account when allocating admission benchmarks for budget places.

\section{References}

1. Federal Law №. 273 of December 29, 2012 (as amended on July 31, 2020) «On Education in the Russian Federation» http://www.consultant.ru/document/cons_doc_LAW_140174/b819c620a8c698de3586 1ad4c9d9696ee0c3ee7a/

2. L.V. Chuprova, O.V. Ershova, Science Vector of Togliatti State University 3, 336-339 (2014)

3. V.S. Stepanova, Bulletin of the KhGAEP 1, 62-69 (2010)

4. M. Townsley, What is the Difference between Standards-Based Grading (or Reporting) and Competency-Based Education? http://www.competencyworks.org/analysis/whatis-the-difference-between-standards-based-grading /

5. O. Miroshnikova, Continuing education: XXI century 2(10) (2015) https://doi.org/10.15393/j5.art.2015.2806

6. I. Kazakova, Scientific-methodical electronic journal "Concept" 11, 2901 - 2905 (2016) http://e-koncept.ru/2016/86613.htm

7. V. Kachalov, Standards and quality 12, 82-87 (2005) 
8. A. Rusanova, Satisfaction as an indicator of the quality of education in a modern university (from the experience of a specific sociological study) https://cyberleninka.ru/article/n/udovletvorennost-kak-pokazatel-kachestvaobrazovaniya-v-sovremennom-vuze-iz-opyta-konkretnogo-sotsiologicheskogoissledovaniya

9. N. Eremina, N. Kislova, Higher education today: on the issue of requirements and quality https://cyberleninka.ru/article/n/vysshee-obrazovanie-segodnya-k-voprosu-otrebovaniyah-k-kachestvu

10. Form «Information on the organization carrying out educational activities in educational programs of higher education - bachelor's programs, specialist programs, master's programs» https://minobrnauki.gov.ru/ru/activity/stat/highed/index.php

11. D.P. Sakas, D.S. Vlachos, S.I. Gikas, Procedia - Social and Behavioral Sciences 73, 345-353 (2013) https://doi.org/10.1016/j.sbspro.2013.02.061

12. V. Demina, I. Usacheva, Economy in industry 12(3), 256-270 (2019) https://doi.org/10.17073 / 2072-1633-2019-3-256-2

13. M.-Á. Revilla-Camacho, F.-J. Cossío-Silva, B. Palacios-Florencio, European Research on Management and Business Economics 23(1), 23-32 (2017) https://doi.org/10.1016/j.iedeen.2016.07.003

14. Edmund Adam, International Journal of Educational Development 76, 102197 (2020) https://doi.org/10.1016/j.ijedudev.2020.102197

15. A. Macris, M. Macris, Annals of the Univ. of Petrosani, Economics 11(3), 147-154 (2011)

16. A. Benson, Journal of Health Economics 32(1), 149-159 (2013) https://doi.org/10.1016/j.jhealeco.2012.09.002

17. M. Nojavan, A. Heidari, D. Mohammaditabar, Socio-Economic Planning Sciences 100816 (2020) doi.org/10.1016/j.seps.2020.100816

18. L. Temizer, A.Turkyilmazb, Procedia - Social and Behavioral Sciences 46 (2012) doi.org/10.1016/j.sbspro.2012.06.150

19. H. Dinçera, S. Yüksela, L. Martínez, Computers \& Industrial Engineering 131, 1-12 (2019) https://doi.org/10.1016/j.cie.2019.03.026

20. C. Munozab, H. Laniadoc, J. Córdoba, Research in Transportation Business \& Management 100519 (2020) https://doi.org/10.1016/j.rtbm.2020.100519. 